\title{
Analysis of the scoring formula of economic criteria in public works procurement
}

\author{
J. L. Fuentes-Bargues ${ }^{1,2, *}$, C. González-Gaya ${ }^{3}$ \\ ${ }^{1}$ Dept. Proyectos de Ingeniería, Universidad Politécnica de Valencia, Valencia, Spain \\ ${ }^{2}$ Dept. Ingeniería Química, Universidad de Valencia, Valencia, Spain \\ ${ }^{3}$ Dept. Ingeniería de Construcción y Fabricación, UNED, Madrid, Spain
}

Email address:

jofuebar@dpi.upv.es (J. L. Fuentes-Bargues), cgonzalez@ind.uned.es (C. González-Gaya)

To cite this article:

J. L. Fuentes-Bargues, C. González-Gaya. Analysis of the Scoring Formula of Economic Criteria in Public Works Procurement, International Journal of Economic Behavior and Organization. Vol. 1, No. 1, 2013, pp. 1-12. doi: 10.11648/j.ijebo.20130101.11

\begin{abstract}
Public works procurement regulates two award procedures from within the same criteria: either the price or a variety of different conditions. Although the question of price may not seem the most important factor to be considered, it is imperative to always be aware of it when bearing in mind the award criteria. Economic scoring formulae (ESF) are numerous and each agency has the authority to determine which will be used for each of their bids, making this article a comparative analysis of all the options. The results show that most formulas give the highest score to the most economic bidder, it is necessary to eliminate the use of formulas that give the highest score to the offers which are closest to the average of all bids submitted. One should always opt for formulas with moderate or strong scoring gradients across various stages or phases, thereby giving more weight to economic analysis, as set out in the various administrative clauses.
\end{abstract}

Keywords: Procurement, Economic Scoring Formulae, Construction, Project Management, Bids

\section{Introduction}

Auctions or the most competitive pricing were the first and clearest characteristics of modern award procedures. The increasing complexity of projects and on the odd occasion extremely low awarded bids threatened the contractual performance and the financial state of the contractor. This was why a lot of research was carried out focussing on determining or establishing optimal price by developing prediction models and bidding strategies [1-4], paying less attention to the analysis of other award criteria [5-9].

On the one hand, current hiring research is based around determining the correct selection criteria and the development of contractor selection models using a multi-criteria analysis of neural network techniques [10-12] in technical AHP-ANP [13] or DEA techniques [14-15]. Another avenue of research is the development of mathematical models that help to make the decision of whether to compete for a contract. And if so, determining the optimum value based on certain criteria and risks for tenderers [16-19]. The latter group may include the development of prediction models based lower rates taking into account historical economic openings of a particular public body [20-21].

Many of these investigations are presented from the point of view of the tenderers, disregarding the fact that legislation does not evolve as fast as the tender in the private sector, and that each government, national, regional and local agency has their individual preferences or arbitrary natures when it comes to the selection the award criteria for public contracts.

Although this paper only contains Spanish tenders documents, the ESF and the variables analyzed are directly applicable to any country where requesting administrations or contracting authorities set an initial tender price against which candidates must underbid (capped tendering or upper-limited priced tendering).

The European Directive 2004/18/EC [22] and in Spain's case, The Royal Decree 3/2011 [23] that approves the Restated Text of the Law on Public Sector Contracts (here in after RTLPSC), govern public procurement. Each public body shall determine the relevant contract documents and the specific characteristics of the work to tender, highlighting among other things the award criteria. The award criteria should be tailored to the technical capabilities of the contracting authority and shall be related to issues directly linked to the subject of the contract, i.e. defining or characterizing the project out to tender. These must not to be confused with bidder-suitability criteria [24-26], which can justify the technical and economic soundness of the tender- 
ers.

The legislation examines two award procedures; the first of which is used when there is only award criterion: the price, and the second procedure is applied when using multiple award criteria in which, although not officially specified, the price will be a factor (Report 28/95 of Advisory Board on State Administrative Contracting, ABSAC [27]). The contract documents shall state the importance of each of the evaluation criterion along with the individual methods and scoring formulae.

If various forms of valuation are used, they are split among measureable criteria by applying different formulae and conditions to make a value judgment. The first will be allocated predetermined formulae and the score will be calculated by applying the appropriate one, these will include aspects such as price, completion time, etc., meanwhile, the scores resulting from the measurable criteria and the value judgement will always be subject to a degree of independent bias because they depend on technician or technicians who perform the assessment.

The European and Spanish regulatory system stipulate that scores resulting from the valuation decision made upon measurable criteria are to be established before the opening of the evaluated criteria based on a formula as a way to avoid any possibility of fraud. Both best practice guidelines and legislation state that the weight of the evaluated criteria based on a formula is greater than the weight of the valuation decision made upon measurable criteria (at least in open or restricted procedures). However, if this weren't the case, the rules laid out in Article 150.2 (RTLPSC) examine the evaluation of these criteria by bringing on technicians with no personal interest or otherwise in the organisation that has promoted the contract.

Competitive bidding in the Spanish construction sector has been, is and will be one of its fundamental pillars, the main core of the work of many Spanish construction companies whether they be local, regional, national or international. In 2006 public bidding reached a record high at 44,205,305,000 euros, maintaining lower yet not so distinct values in successive years (2007 to $37,399,432,000$ euros, 2008 to $38,495,264,000$ euros and 2009 to 35,354,070,000 euros) when the public sector had to invest vast capital in order to offset the collapse of the private construction sector; particularly in the residential construction subsector. The current economic situation means that European governments and especially the Spanish government have had to limit state borrowing and drastically reduce the amount of public investment in new infrastructure. In total, 11,781,358 euros in 2011, a number not dissimilar to values from the $90 \mathrm{~s}$, but despite all that, tender reference in the Spanish construction sector is undeniable.

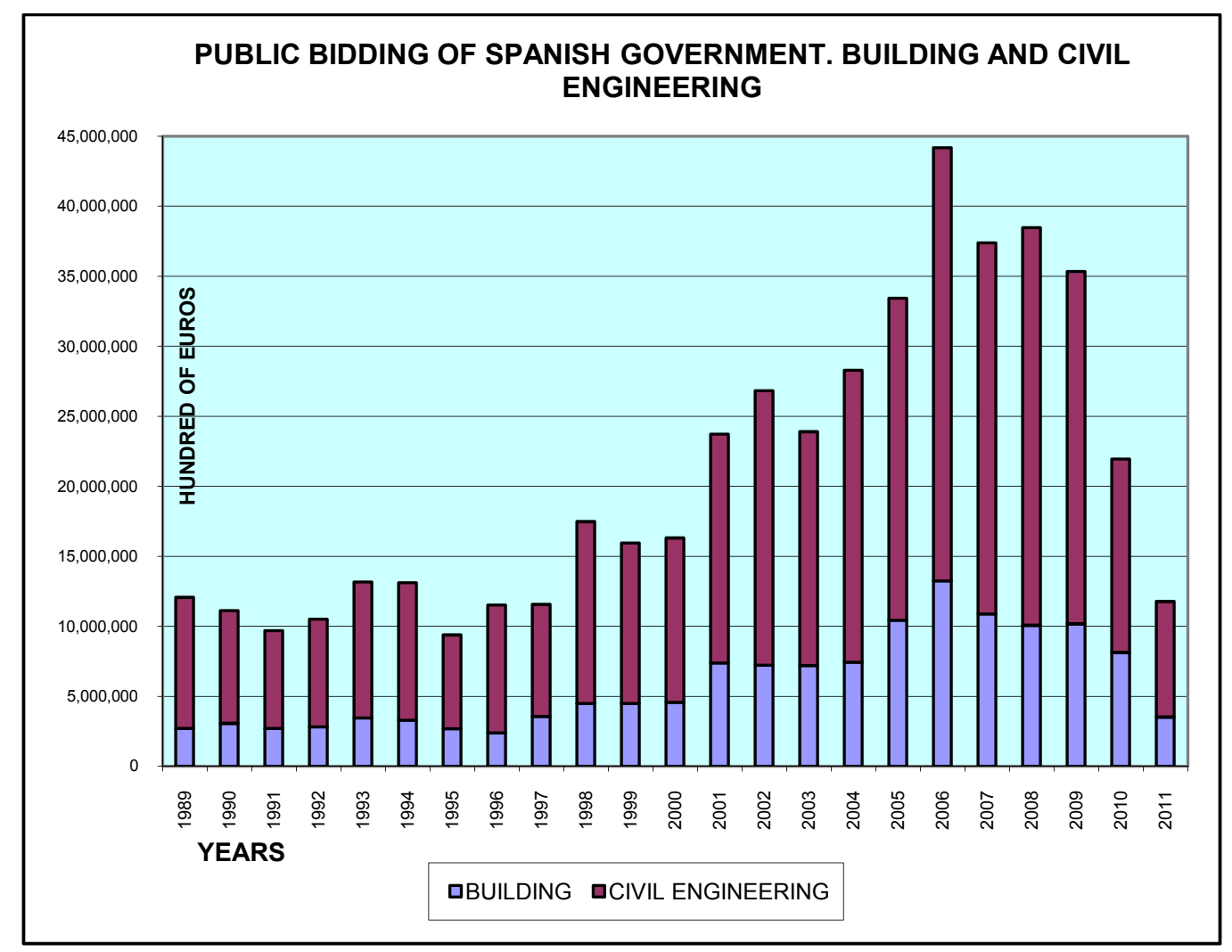

Figure 1. Public Bidding of Spanish Government. Building and Civil Engineering. Source: Data from Ministry of Development. Spanish Government.

Despite the great importance of public procurement in the construction sector and the economic volume involved, there are no specific regulations or guidelines about the scoring formulae behind the economic criteria [28]. It seems that with tenders based wholly on price, the most economically sound bid is the best bid and the influence of the eco- 
nomic formula is not so strong. However for tenders with several criteria to be considered, the best bid will be the one which obtains the highest overall score in all the criteria measured. As such, mid-range scores based on price become particularly significant.

This data will be used to determine what are the criteria or scoring formulae used today, and to analyse their performance in order to establish less arbitrary selection guidelines on behalf of the contracting authorities.

\section{Material and Methods}

\subsection{Data collection}

The starting point for the analysis of the criteria or scoring formulae behind economic criteria was to obtain data from a sample of one hundred works projects, bid on by the public sector, which reflect different characteristics of the sector: local, provincial, regional and national Civil Works and Building subsectors, several award allocation criteria where price had a certain importance, etc. The data required for drawing up the study sample were the administrative terms and techniques, the invitation to tender and project execution, the budget and the annex of the justification of indirect costs.

Despite the principle of equality and transparency in which the legislation enacts in its provisions, and the creation of "Contractor Profile" in each and every website belonging to the contracting authorities, data collection has been an arduous task. Due in part to the administrations having many construction projects in copy shops or because of their distribution being carried out upon on payment of a fee. From this process comes the first of many observations: why doesn't the government use twenty-first century media resources to allow free access to documentation?

For each of the works studied and after analysis of the documentation a table was drawn up (Figure 2) with the following fields; the first block corresponds to the Contracting Authority Data (name, unit, URL of Contractor profile and geographic scope), a second block which reflects the Contract Data (type, description, batch, file number, date of issue and date of tender) and a third block, called Processing and Procedure which reflect data on the type of procedure, the type of processing, how to award the tender, the bidding budget, annuity, the formula (if available) and price revision and the required contractor's classification.

\begin{tabular}{|c|c|c|}
\hline \multicolumn{3}{|c|}{ FILE TENDER NUMBER } \\
\hline \multicolumn{3}{|c|}{ CONTRACTING AUTHORITY DATA } \\
\hline \multicolumn{3}{|l|}{ NAME } \\
\hline \multirow{2}{*}{\multicolumn{3}{|c|}{$\begin{array}{l}\text { UNIT } \\
\text { URL OF CONTRACTOR PROFLLF }\end{array}$}} \\
\hline URL OF CONTRACTOR PROFILE & & \\
\hline \multirow{2}{*}{\multicolumn{3}{|c|}{ GEOGRAPHICAL SCOPE }} \\
\hline & & \\
\hline \multicolumn{3}{|l|}{ TYPE } \\
\hline \multicolumn{3}{|l|}{ DESCRIPTION } \\
\hline \multirow{2}{*}{\multicolumn{3}{|c|}{ BATCH DIVISION }} \\
\hline \multirow{2}{*}{\multicolumn{3}{|c|}{$\begin{array}{l}\text { NUMBER OF BATCHES } \\
\text { FILE NUMBER }\end{array}$}} \\
\hline & & \\
\hline \multicolumn{3}{|l|}{ DATA OF ISSUE } \\
\hline \multirow{2}{*}{\multicolumn{3}{|c|}{ PROCESSING AND PROCEDURE }} \\
\hline & & \\
\hline \multicolumn{3}{|l|}{ TYPE OF PROCEDURE } \\
\hline \multicolumn{3}{|l|}{ TYPE OF PROCESSING } \\
\hline \multirow{2}{*}{\multicolumn{3}{|c|}{$\begin{array}{l}\text { AWARD FORM } \\
\text { PDDING RUDGET }\end{array}$}} \\
\hline \multirow{2}{*}{\multicolumn{2}{|c|}{$\begin{array}{l}\text { BIDDING BUDGET } \\
\text { YAT }\end{array}$}} & \\
\hline VAT & & \\
\hline \multicolumn{3}{|l|}{ TOTAL BUDGET } \\
\hline \multicolumn{3}{|l|}{ ANNUITY } \\
\hline \multicolumn{3}{|l|}{$\begin{array}{l}\text { NUMBER AND BUDGET OF THE } \\
\text { ANNUITIES }\end{array}$} \\
\hline \multirow{2}{*}{\multicolumn{3}{|c|}{$\begin{array}{l}\text { PRICE REVISION } \\
\text { FORMULA OF PRICE REYISION }\end{array}$}} \\
\hline \multirow{2}{*}{$\begin{array}{l}\text { FORMULA OF PRICE REVISION } \\
\text { CONTRACTOR'S CLASSIFICATION }\end{array}$} & & \\
\hline & & \\
\hline \multicolumn{3}{|l|}{$\begin{array}{l}\text { DESCRIPTION OF CONTRACTOR'S } \\
\text { CLASSIFICATION }\end{array}$} \\
\hline \multicolumn{3}{|c|}{ DESCRIPTION OF THE AWARD CRITERIA } \\
\hline \multicolumn{3}{|c|}{ DESCRIPTION OF THE ECONOMIC CRITERIA } \\
\hline \multicolumn{2}{|c|}{$\begin{array}{l}\text { DESCRIPTION OF THE DISPROPORTIONALITY CRITERIA } \\
\end{array}$} & \\
\hline \multicolumn{3}{|c|}{$\begin{array}{l}\text { PROJECT DATA } \\
\end{array}$} \\
\hline \multicolumn{3}{|c|}{\begin{tabular}{lll|l} 
BUDGET & EXECUTION & MATERIAL & \\
(BEM)
\end{tabular}} \\
\hline \multicolumn{3}{|l|}{$\begin{array}{l}\text { LABOUR (EUR or \%BEM) } \\
\text { MATERIALS (EUR or \%BEM) } \\
\text { EQUIPMENT (EUR or \% \%EM) }\end{array}$} \\
\hline \multicolumn{3}{|l|}{ DATA EXECUTION } \\
\hline LABOUR TIMESCALES & & \\
\hline INDIRECT COSTS & & \\
\hline JUSTIFIC & TON OF INDIRECT COSTS & \\
\hline
\end{tabular}

Figure 2. Table for the study of the Contract Documents of the Public Procurements.

In this third block of information, fields for the description of the award criteria are also reflected with a special focus on a more detailed economic scoring formula (price) and formulas or guidelines for determining whether there are abnormal or disproportionate deals.

Finally, a fourth block called Project Data reflects data on 
Budget Execution Material (BEM), on its disintegration through labour, materials, equipment and indirect costs, as well as data execution time and estimated labour timescales (if available). Justification is ultimately reflected in the percentage of indirect costs used in developing the project budget.

The data collected is vast and varied and can characterise the sample from different points of view. The most relevant aspects are reflected in the following graphs (Figures 3-6). The sample presented mainly projects with ordinary processes, open procedure and a competition based award allocation. This represents almost $50 \%$ of the Building and Civil Works subsector and the different economic strata and geographical reach as indicated above.

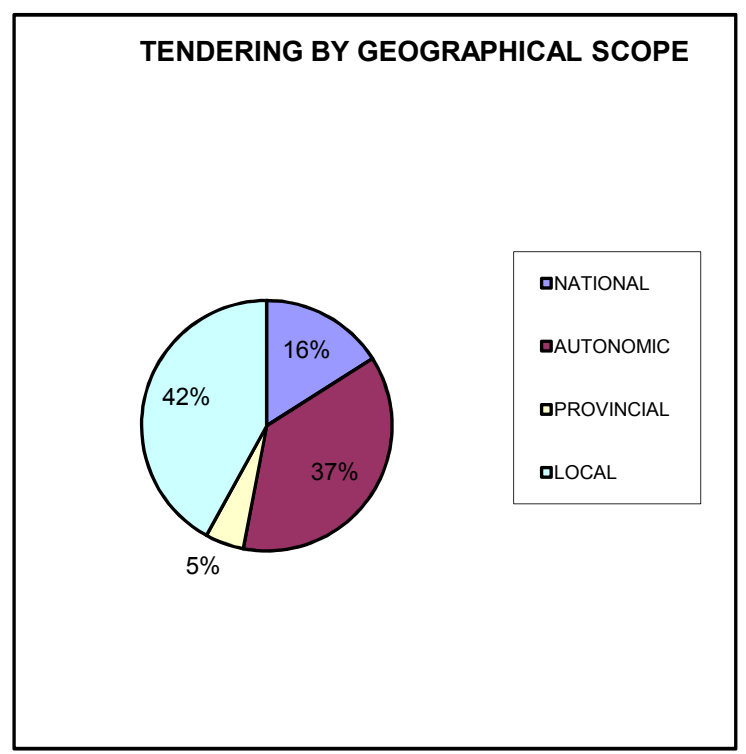

Figure 3. Tendering by Geographical Scope from Works Projects studied.

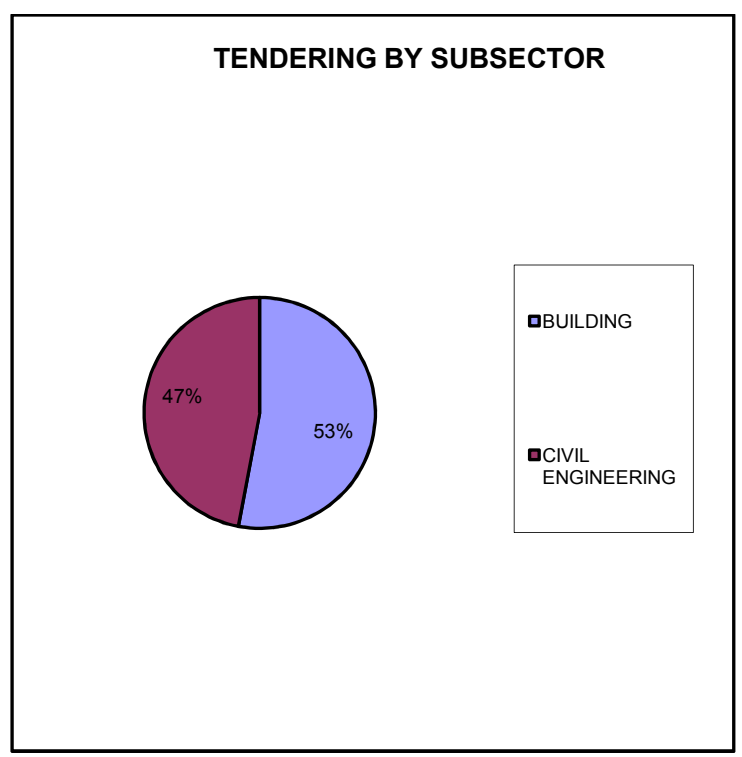

Figure 4. Tendering by Subsector from Works Projects studied.

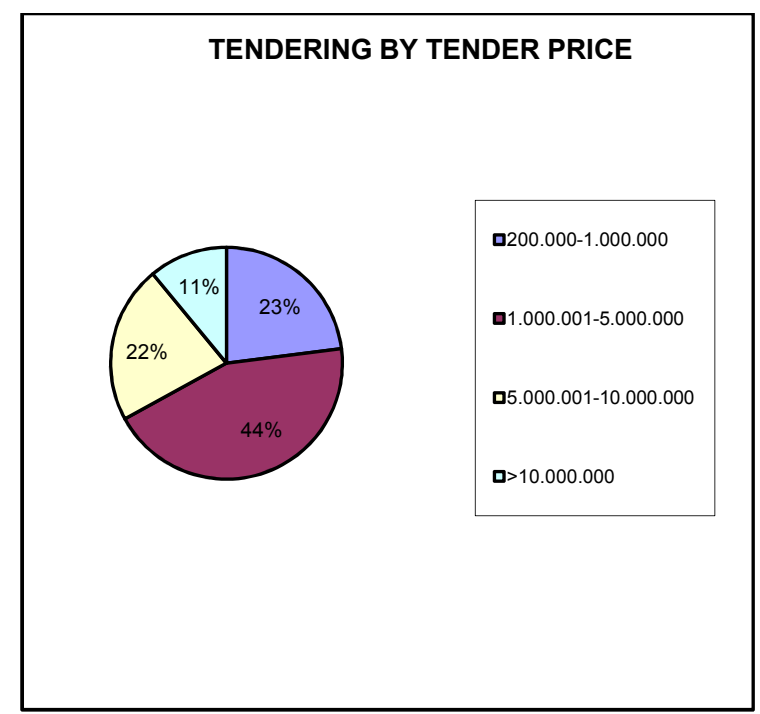

Figure 5. Tendering by Tender Price from Works Projects studied.

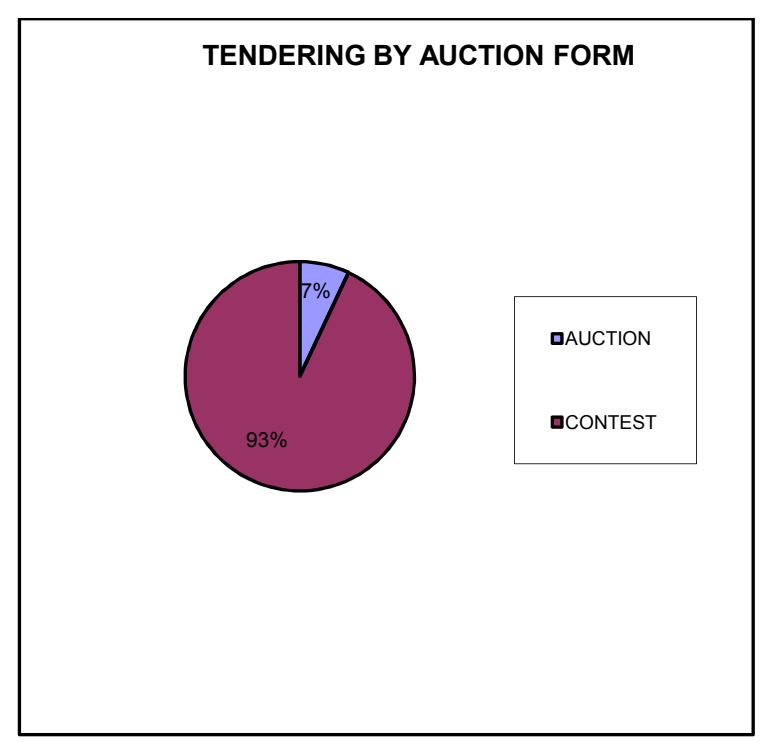

Figure 6. Tendering by Auction Form from Works Projects studied.

\subsection{Analysis}

A first analysis of the sample with respect to the economic criteria, as seen in Figure 7, reflects the economic weight of the total economic criteria of the tender is apparent in $40 \%$ of cases; between 41 and 50 points based on total of 100 points. Another point to note is that the use of price as the sole criterion for the award allocation (auction) is practically residual $(7 \%)$ with respect to the award allocation through several criteria (competition).

In the study sample, many scoring criteria or economic formulae have been pinpointed and grouped according to their characteristics into ten groups which are described below. This indicates the criteria that have subsequently been used in the mathematical analysis.

Before we must define the concept of "Bidder's Drop". It is the discount or bid reduction on the tender price of a contract $\left(\mathrm{P}_{\mathrm{t}}\right)$ submitted by a given contractor i for a particular capped tender. It is mathematically expressed as: 


$$
D_{i}=\left(1-\frac{B_{i}}{P_{t}}\right) \cdot 100
$$

Where:

$\mathrm{D}_{\mathrm{i}}$ is the Drop of bidder $\mathrm{i}$ (expressed in \%)

$\mathrm{B}_{\mathrm{i}}$ is the Bid (expressed in monetary values)

$P_{t}$ is the Tender price (expressed in monetary values)

Group I. In this group there are two criteria. For both, the highest score is awarded to the lowest bidder, while the first one (Ia) with zero points to supply the type of competition $\left(\mathrm{P}_{\mathrm{t}}\right)$ is valued. In the second of the criteria $(\mathrm{Ib})$ zero points are allocated to the highest bidder resulting in a linear interpolation between the two values for the remaining intermediary deals.

Group II. The maximum score is awarded to the lowest bidder. The score is reached for the following deals in a linear manner over several steps. These steps are predefined by fixed amounts or the average of the bids submitted is used. They differ in the two criteria analyses.
The first one (IIa) uses a polygonal function divided into three sections, the first taken from the offer rate and the Mean Drop $\left(D_{m}\right)$, making the $D_{m} 87.5 \%$ of the score. This is followed by a second step in which the upper limit is found in the Mean Drop plus five percentage points $\left(D_{m}+5\right)$ with a maximum score of $95 \%$. Finally, a last step in which the value will match the maximum drop, which in any case shall not exceed the mean drop plus ten percentage points (define the criterion of disproportionality of the offers in the scoring formula itself).

The second polygonal function of this group of criteria (IIb) has two steps using, as an inflection point, the arithmetic average of the percentages of the Mean Drop $\left(D_{m}\right)$. The formulas expressing the score for each interval are:

Criterion IIb.1 (for the upper step)

$$
S_{i}=85+(90-85) \cdot\left[\frac{D_{i}-D_{m}}{D_{\text {max }}-D_{m}}\right]
$$

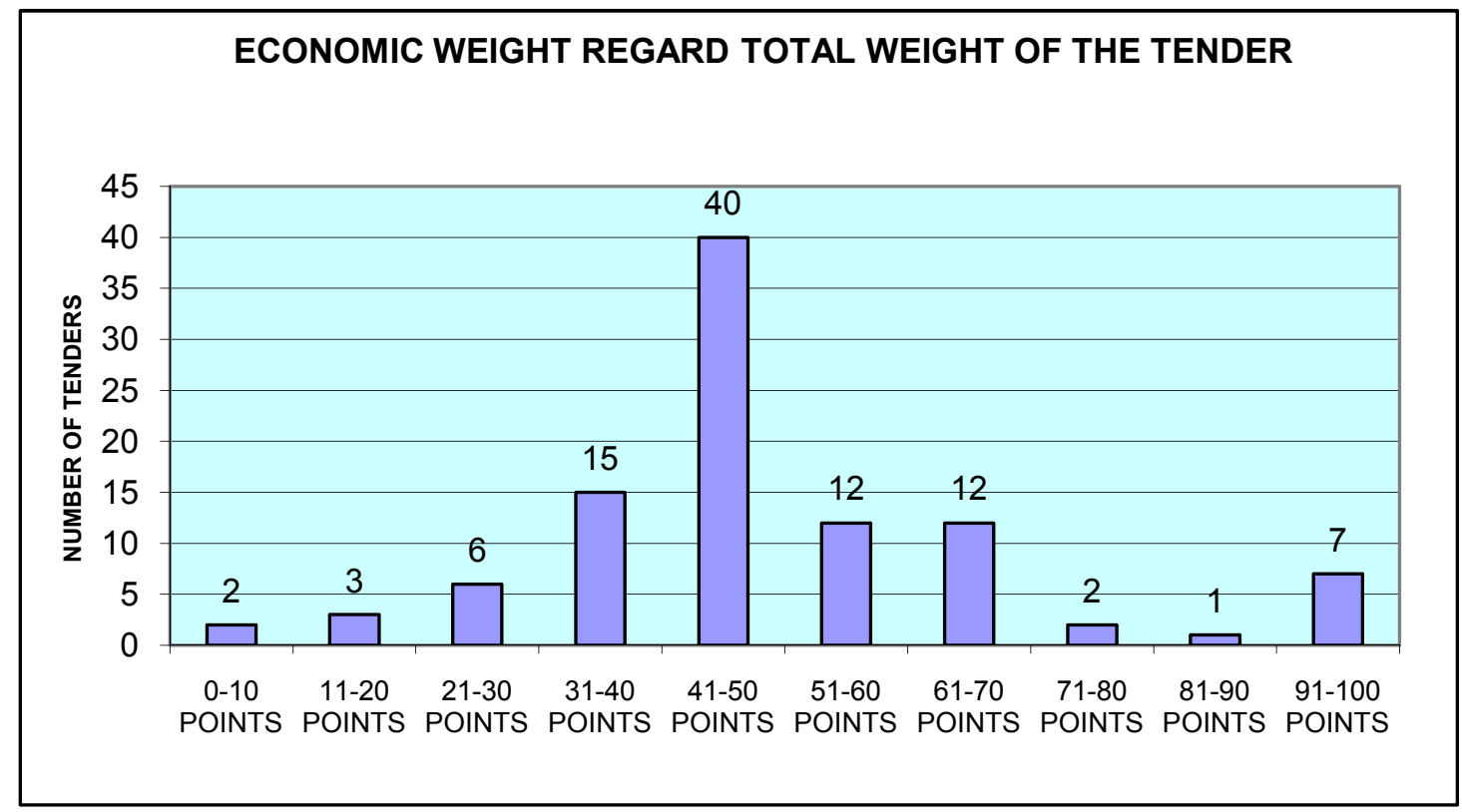

Figure 7. Economic Weight regard Total Weight of the Tender (Total $=100$ points).

and for the lower step using the next formula:

$$
S_{i}=85-\left[\left(D_{m}-D_{i}\right) \cdot 2\right]
$$

Where:

$\mathrm{S}_{\mathrm{i}}$ is the scoring of the bidder $\mathrm{i}$ (expressed in points)

$\mathrm{D}_{\mathrm{i}}$ is the Drop of bidder $\mathrm{i}$ (expressed in \%)

$D_{m}$ is the Mean Drop (expressed in \%)

$\mathrm{D}_{\max }$ is the Maximum Drop (expressed in \%)

Group III. The maximum score is awarded to the most economical bid without explicitly indicating the scores for the rest of the offers in the contract documents.

Group IV. This section is used to reflect different scoring criteria that are dissimilar to other selection criteria. Four scoring formulae have been studied.

Criterion IVa.

$$
S_{i}=W_{p}-W_{p} \cdot\left[\frac{\left(D_{\max }-D_{i}\right)^{2}}{\left(D_{\max }-1 / 2 \cdot D_{\min }\right)^{2}}\right]
$$

Criterion IVb.

$$
\begin{gathered}
S_{i}=50 \cdot\left[\frac{\left(P_{t}+\delta\right)-B_{i}}{\left(P_{t}+\delta\right)-\left(B_{\min }-\delta\right)}\right] \\
\delta=\sigma \cdot \sqrt{n} \\
\sigma=\sqrt{\frac{1}{n} \sum_{j=1}^{n}\left(B_{i}-B_{m}\right)^{2}}
\end{gathered}
$$

Where:

$\mathrm{B}_{\mathrm{i}}$ is the Bid (expressed in monetary values) 
$\mathrm{B}_{\mathrm{m}}$ is the Mean Bid (expressed in monetary value)

$\mathrm{B}_{\min }$ is the Lowest Bid (expressed in monetary value)

$\mathrm{n}$ is the Number of bidders

$\mathrm{P}_{\mathrm{t}}$ is the Tender price (expressed in monetary values)

$\mathrm{W}_{\mathrm{p}}$ is the Maximum weight of the criterion price (expressed in points)

$\delta$ is a parameter calculated by the expression (6)

$\sigma$ is the Standar deviation

Criterion IVc.

$$
S_{i}=W_{p}-\frac{9}{10} \cdot W_{p} \cdot \frac{\left(D_{\max }-D_{i}\right)^{2}}{\left(D_{\max }-\frac{D_{\min }}{2}\right)^{2}}
$$

\section{Criterion IVd}

$$
S_{i}=\left[\frac{P_{t}-B_{i}}{P_{t}}\right] \cdot\left[\frac{W_{p} \cdot 100}{D_{m}+15}\right]
$$

Group V. The maximum score is given to offers close to the average of the bids submitted. Other offers (and their low averages) which vary from that average (both above and below) are penalized and therefore score lower.

Criterion V.

$$
\begin{gathered}
S_{i}=\frac{W_{p}}{5} \cdot\left\{1+4 \cdot\left[\frac{P_{t}-B_{i}}{P_{t}-B_{m}}\right]\right\}, s i B_{i} \geq B_{m} \\
S_{i}=\frac{W_{p}}{5} \cdot\left\{1+4 \cdot\left[\frac{P_{t}-B_{m}}{P_{t}-B_{i}}\right]\right\}, s i B_{i}<B_{m}
\end{gathered}
$$

Group VI. All companies obtain a minimum score for their financial proposals and the rest of the score, right up to the maximum awarded to the lowest bid, is interpolated linearly or is given a proportional score across several steps.

Two criteria have been analyzed within this group. The first one (VIa) has a low value of $15.9 \%$ which is represented as the turning point.

If the maximum drop is less than or equal to $15.9 \%$ the score shall be obtained by linear interpolation between 30 points for a drop of $0 \%$ and one hundred points for the maximum drop according to the following statements:

Criterion VIa.1

$$
S_{i}=30+70 \cdot \frac{D_{i}}{D_{\max }}
$$

When the maximum drop is bigger than $15.9 \%$, the offers will be pointed from a drop of $0 \%$ until a bid of $15.9 \%$, according to the next expression:

Criterion VIa.2

$$
S_{i}=30+D_{i} \cdot \frac{60}{15,90}
$$

And from a drop of $15.9 \%$ until the maximum drop with the expression:

Criterion VIa.3

$$
S_{i}=90+10 \cdot \frac{D_{i}-15,9}{D_{\text {max }}-15,9}
$$

The second criterion of this group (VIb) gives a minimum score of ten points to each bidder, and the rest of points through a expression with a only step depending of the lowest bid and the mean bid.

Criterion $\mathrm{VIb}$

$$
S_{i}=100-10 \cdot \frac{B_{i}-B_{\min }}{B_{m}-B_{\min }}
$$

Group VII. The maximum score is awarded to the lowest bid, giving the other companies a score which is proportionate to the offer. There are two criteria, the formula VIIa that works with the bids, and the criterion VIIb that the formula which works with the drops.

Group VIII. A number of points will be awarded for each drop as a percentage of the bid price; the maximum score is usually limited. This group analysed two criteria: VIIIa grants a maximum of ten points for each five lower percentage points, and VIIIb criterion gives the highest score to the lowest bidder and the rest will have one point subtracted for each $0.5 \%$ (or the appropriate proportion) of a price increase on the lowest bid.

Group IX. The maximum score goes to the lowest bid, calculating the score for all remaining bids using the following formula:

Criterion IX.

$$
\begin{gathered}
S_{i}=K \cdot \varepsilon \\
K=1+\left(\frac{45-\varepsilon}{45}\right)
\end{gathered}
$$

Where:

$\mathrm{K}$ is a parameter calculated by the expression (17)

$\varepsilon$ is the quotient between the Bidder's i Drop $\left(D_{i}\right)$ and the Maximum Drop $\left(\mathrm{D}_{\max }\right)$, expressed both in \%.

Group X. The maximum score goes to the lowest bid, obtaining the appropriate score of other companies but taking into account the difference with regard to the minimum bid or the average bid from bidding companies. The scoring formula has been analysed, where a priori the maximum score of the criterion for deals of less than the arithmetic average of the bids submitted, will be dictated by the limitation of drop or disproportionate tenders.

Criterion X.

$$
S_{i}=\left[5-\frac{10 \cdot\left(B_{i}-B_{m}\right)}{B_{m}}\right] \cdot 5
$$

Fig. 8 shows the distribution according to the groups described, the formulas or scoring criteria of procurement specifications from the study sample, where group VII's criteria is shown as the most widely used with $38 \%$, in other words, the highest score is awarded to the lowest or cheapest bid. The other companies receive a proportional score ac- 
cording to the offer or the lowest rate incurred. Subsequently, closely-related values which differ greatly from the criteria of Group VII are from the group VI criteria with $11 \%$, the criteria which form groups II and III with $10 \%$ and the criteria set $\mathrm{X}$ with $9 \%$ respectively.

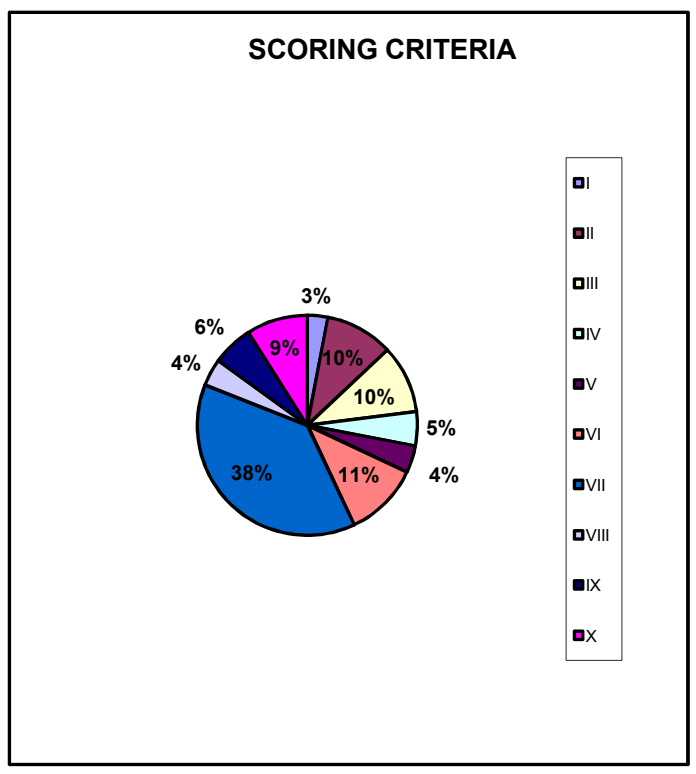

Figure 8. Formulas or Scoring Criteria.

\subsection{Applying Data from Projects}

Having identified the main scoring criteria, it is necessary to study their behaviour by applying data from the economic opening of two projects; one, a project from the Building subsector with few bidders, and the other from the Civil Engineering subsector with many bidders. The project from the Building subsector is the construction of the SUNP VI
Sports Centre by the Council of Sagunto, file 59/90, with a budget of EUR 2,786,034.48 tender + VAT. Whereas the project from the Civil Engineering subsector is for the repaving of the streets within the Huerta Nueva area and The Sax Avenue in Elda (Alicante); tendered by the Department of Infrastructure and Transport of the Generalitat Valenciana, file: 2010/09/0103, with a budget of EUR 1,366,444.98 tender + VAT.

In this case and in order to standardise the comparison between the various criteria or formulas, all maximum bids will score 50 points, and the scoring of the remaining bids will be obtained in accordance with the provisions of each criterion.

Table 1. Economic Opening Results for SUNP VI Sports Centre by the Council of Sagunto

\begin{tabular}{lccc}
\hline Tendering Company & & Bid (Euros) & Drop (\%) \\
\hline Via Latina S.A. & A & $2,667,273.43 €$ & 4.26 \\
Elecnor & B & $2,758,174.14 €$ & 1.00 \\
$\begin{array}{l}\text { Secopsa } \\
\text { Construcciones S.A. }\end{array}$ & C & $2,769,742.11 €$ & 0.58 \\
Valcomar S.A. & D & $2,307,981.50 €$ & 17.16 \\
Intersa Levante S.A. & E & $2,368,129.31 €$ & 15.00 \\
\hline
\end{tabular}

Table 2. Economic Opening Results for the repaving of the streets within the Huerta Nueva area and the Sax Avenue in Elda (Alicante).

\begin{tabular}{llll}
\hline Tendering Company & & Bid (Euros) & Drop (\%) \\
\hline Electricidad Paquete-Mainco & B1 & $1,355,932.21$ & 0.77 \\
Gestaser-Secopsa & B2 & $1,332,016.26$ & 2.52 \\
Rover Alcisa & B3 & $1,328,000.00$ & 2.81 \\
Mac-Puar & B4 & $1,325,451.63$ & 3.00 \\
Servicios Industriales & B5 & $1,318,619.41$ & 3.50 \\
Asfaltos Guerola-Symetra & B6 & $1,309,054.29$ & 4.20 \\
Assignia, S.A.-Ing. & B7 & $1,298,669.31$ & 4.96 \\
Del Agua Y La Energia & B8 & $1,298,122.72$ & 5.00 \\
Vaseco-Villegas & B9 & $1,288,782.94$ & 5.68 \\
Saico & B10 & $1,284,458.28$ & 6.00 \\
Beneaguas-Electrisur & B11 & $1,283,775.06$ & 6.05 \\
Construcciones & B12 & $1,277,659.35$ & 6.50 \\
Proyme Alginet & B13 & $1,258,085.89$ & 7.93 \\
Edificaciones Castelló-Urbamed & & & \\
S.A. De Riegos & Camios Y Obras & B &
\end{tabular}




\begin{tabular}{|c|c|c|c|}
\hline Tendering Company & Bid (Euros) & Drop (\%) & \\
\hline Ezentis Infraestructuras & B14 & $1,256,856.09$ & 8.02 \\
\hline Pavasal & B15 & $1,250,559.46$ & 8.48 \\
\hline Grupo Generala-Reticulares & B16 & $1,249,067.36$ & 8.59 \\
\hline Construcciones Frances & B17 & $1,249,019.00$ & 8.59 \\
\hline Cyes Infraestructuras & B18 & $1,246,197.82$ & 8.80 \\
\hline $\begin{array}{l}\text { Bm3 Obras Y } \\
\text { Servi-Riegos Vinalopó }\end{array}$ & B19 & $1,241,688.55$ & 9.13 \\
\hline Torrescamara & $\mathrm{B} 20$ & $1,232,533.37$ & 9.80 \\
\hline Coinger & $\mathrm{B} 21$ & $1,229,800.48$ & 10.00 \\
\hline Grupo Bertolín-Procumasa & $\mathrm{B} 22$ & $1,225,154.57$ & 10.34 \\
\hline Ecisa & $\mathrm{B} 23$ & $1,225,000.00$ & 10.35 \\
\hline Ocide & B24 & $1,222,421.68$ & 10.54 \\
\hline Binaria & B25 & $1,213,403.14$ & 11.20 \\
\hline Becsa & B26 & $1,207,720.72$ & 11.62 \\
\hline Jotsa-Geosa & $\mathrm{B} 27$ & $1,206,530.97$ & 11.70 \\
\hline $\begin{array}{l}\text { Serrano Aznar } \\
\text { Obras Publicas }\end{array}$ & B28 & $1,201,378.00$ & 12.08 \\
\hline $\begin{array}{l}\text { Dopema-Esclapes } \\
\text { E Hijos }\end{array}$ & B29 & $1,189,490.36$ & 12.95 \\
\hline Enrique Ortiz E Hijos & $\mathrm{B} 30$ & $1,183,103.45$ & 13.42 \\
\hline Arcion & B31 & $1,172,683.08$ & 14.18 \\
\hline Adesval-Electotecnica Morales & B32 & $1,168,310.46$ & 14.50 \\
\hline $\begin{array}{l}\text { Chm Obras } \\
\text { E Infraestructuras }\end{array}$ & B33 & $1,159,291.92$ & 15.16 \\
\hline Intersa Levante & B34 & $1,116,802.00$ & 18.27 \\
\hline
\end{tabular}

\section{Results and Discussion}

The graphical representation of the scores of the different economic criteria, from lowest to highest, provides us with a curve that we can call [25] Scoring Gradient. This curve shows the highest and the lowest scoring losses that occur when a bidder walks away from the lowest rates or the best scores.

The slope of the score curve is one factor that bidders take into account when deciding on their final offer. Steep curves create the need to bid more boldly for a greater score in order to distance oneself from ones competitors, however gentle slopes in the curve can generate less risky deals that may be offset in the valuation of other aspects (technical procedure, environmental measures, quality control guarantees, etc.). This aspect can be seen (Tables 3 and 4) for the criteria VIb, VIIa and X where the difference between the score of the minimum bid and maximum bid varies between eight and ten points in both tenders, regardless of the number of bidders and the standard deviation of the bids.

The Scoring Gradient for the different formulas originates from various points, for the criterion $\mathrm{Ib}$, it is performed at zero and the highest bid wins. For other criteria, the start of the curve depends on the distance between the highest bid and the tender price or the average of the bids submitted. What is remarkable is that the criteria located within the group VI where bidders are assures a minimum score (30 out of 100 on the criterion $\mathrm{VIa})^{1}$ to which, according to the relevant formula, points will be added corresponding to the drop set out by the bidder. This minimum score confirms the gentle slope of the VIb criterion and influences the cases where the lowest maximum falls below the drop (15.9\%) as indicated in the criterion VIa.

Regarding the final point of the curve, it is also advisable to make an assessment following the guidelines and directives of the interpretations of the current legislation. According to which, the lowest bid should receive the highest score from the economic criteria, but this is not so with all ESF (criteria IVb, IVd, V and X). For the first three criteria, each one introduces the reference to tender price and the average of the offers into the formulae either directly or through parameters which depend on the standard deviation of the bids. This means intermediate slopes of the score curves which are more or less pronounced depending on the

\footnotetext{
${ }^{1}$ With the standardization of the score to 50 points, and in order to carry out the comparison of this article, a minimum score of 15 points will be awarded.
} 
number of bidders and the offers available. For example, the $\mathrm{IVb}$ criterion yields a score difference of 11.17 for the work of the civil works subsector in contrast with 34.33 from the building subsector work.

Table 3. Table-Summary by applying the ESF to the data from the economic opening results of the Project from the Building Subsector.

\begin{tabular}{|c|c|c|c|c|}
\hline Criteria & Maximum Score & Minimum Score & Score Difference & Economic Difference \\
\hline Ia & 50.00 & 1.70 & 48.30 & $461,760.61$ \\
\hline $\mathrm{Ib}$ & 50.00 & 0.00 & 50.00 & $461,760.61$ \\
\hline IIa & 50.00 & 3.37 & 46.63 & $461,760.61$ \\
\hline $\mathrm{IIb}$ & 50.00 & 33.19 & 16.81 & $461,760.61$ \\
\hline III & 50.00 & -- & -- & -- \\
\hline IVa & 50.00 & 1.72 & 48.28 & $461,760.61$ \\
\hline $\mathrm{IVb}$ & 42.77 & 8.44 & 34.33 & $461,760.61$ \\
\hline IVc & 50.00 & 5.00 & 45.00 & $461,760.61$ \\
\hline IVd & 28.60 & 0.97 & 27.62 & $461,760.61$ \\
\hline V & 32.43 & 13.08 & 19.35 & $102,468.68$ \\
\hline VIa & 50.00 & 16.10 & 33.90 & $461,760.61$ \\
\hline $\mathrm{VIb}$ & 50.00 & 41.33 & 8.67 & $461,760.61$ \\
\hline VIIa & 50.00 & 41.66 & 8.34 & $461,760.61$ \\
\hline VIIb & 50.00 & 1.70 & 48.30 & $461,760.61$ \\
\hline VIIIa & 50.00 & 12.50 & 37.50 & $461,760.61$ \\
\hline VIIIb & 50.00 & 9.99 & 40.01 & $461,760.61$ \\
\hline IX & 50.00 & 3.35 & 46.65 & $461,760.61$ \\
\hline$X$ & 30.17 & 21.20 & 8.97 & $461,760.61$ \\
\hline
\end{tabular}

Table 4. Table-Summary by applying the ESF to the data from the economic opening results of the Project from the Civil Engineering Subsector.

\begin{tabular}{|c|c|c|c|c|}
\hline Criteria & Maximum Score & Minimum Score & Score Difference & Economic Difference \\
\hline $\mathrm{Ia}$ & 50.00 & 2.11 & 47.89 & $239,130.21$ \\
\hline $\mathrm{Ib}$ & 50.00 & 0.00 & 50.00 & $239,130.21$ \\
\hline IIa & 50.00 & 3.86 & 46.14 & $239,130.21$ \\
\hline IIb & 50.00 & 26.59 & 23.41 & $239,130.21$ \\
\hline III & 50.00 & -- & -- & -- \\
\hline IVa & 50.00 & 2.13 & 47.87 & $239,130.21$ \\
\hline $\mathrm{IVb}$ & 30.83 & 19.66 & 11.17 & $239,130.21$ \\
\hline IVc & 50.00 & 6.91 & 43.09 & $239,130.21$ \\
\hline IVd & 38.50 & 1.62 & 36.88 & $239,130.21$ \\
\hline V & 49.66 & 13.53 & 15.58 & $109,734.39$ \\
\hline VIa & 50.00 & 16.45 & 33.55 & $239,130.21$ \\
\hline $\mathrm{VIb}$ & 50.00 & 41.29 & 8.71 & $239,130.21$ \\
\hline VIIa & 50.00 & 41.18 & 8.82 & $239,130.21$ \\
\hline VIIb & 50.00 & 2.11 & 47.89 & $239,130.21$ \\
\hline VIIIa & 50.00 & 19.23 & 30.77 & $239,130.21$ \\
\hline VIIIb & 50.00 & 7.18 & 42.82 & $239,130.21$ \\
\hline IX & 50.00 & 4.12 & 45.88 & $239,130.21$ \\
\hline $\mathrm{X}$ & 30.23 & 20.64 & 9.59 & $239,130.21$ \\
\hline
\end{tabular}


Another notable aspect of the results shown in Figures 9 and 10 is the criterion $\mathrm{V}$, where the maximum score is not obtained by the company which made the best financial offer but by the company whose offer was the closest to the average of all bids submitted. This fact actually contradicts the principles of the European and Spanish legislations, which were explicitly set out by the European Commission [29] in and by the ABSAC [30]. As shown in Figure 8 in the sample studied used this approach or something very similar in $4 \%$ of the bids.

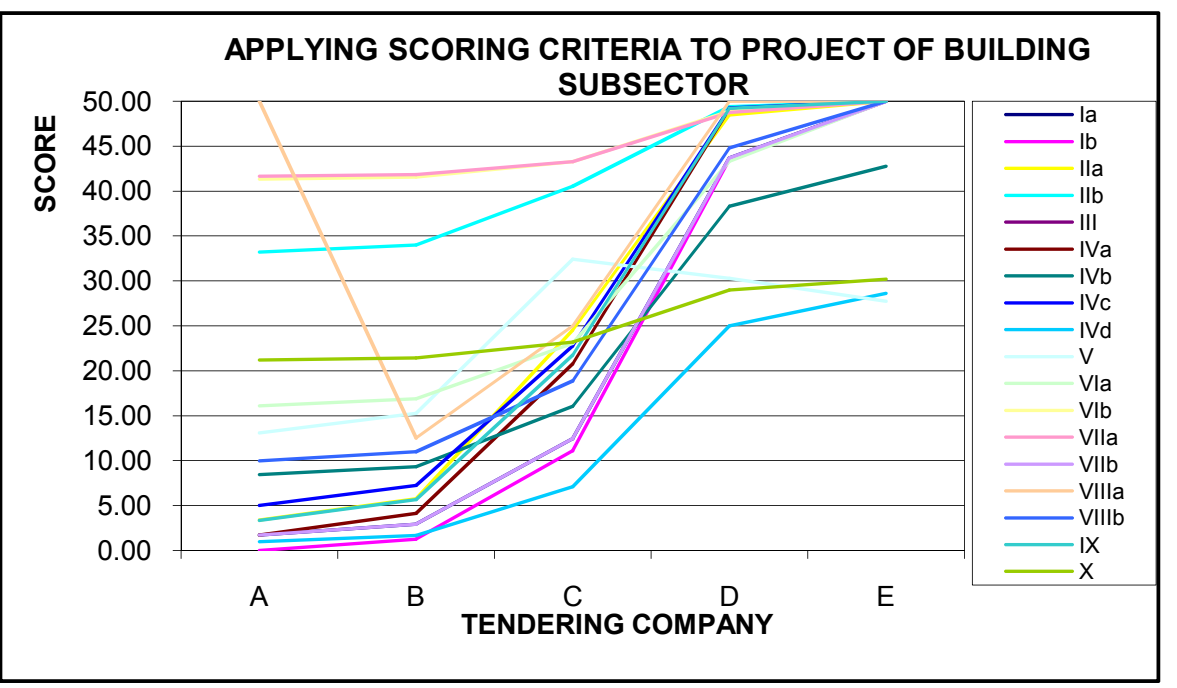

Figure 9. Applying Scoring Criteria to data from the economic results of the Project of Building Subsector.

The VIIIa criterion, which gives the score based on drops, allows many bidders to achieve the highest score once they have passed the threshold. If this is very low the same thing can happen as with the economic results of the civil works subsector in which of the thirty-four bidders, all except for one get the highest score, completely negating the weight of the economic criterion.

It is also important to note the VIIa criterion, a criterion in which the score obtained is in proportion to the tender price and works with the financial bids in euros. Score loss amongst the less risky deals with regards to on the most economically advantageous offer is not as high when working with economic value (bids) as the drops.

Finally, the criterion IIb, whose high score for the highest bid and whose moderate gradient score (16.81 and 23.41 points difference between the building works and the civil engineering subsectors respectively) is due to the scoring formula for companies whose bids fall below the mean offer, minimized their points losses by implementing a coefficient (equal to 2) at the lower end of the scoring formula scale (IIb. 2 criterion).

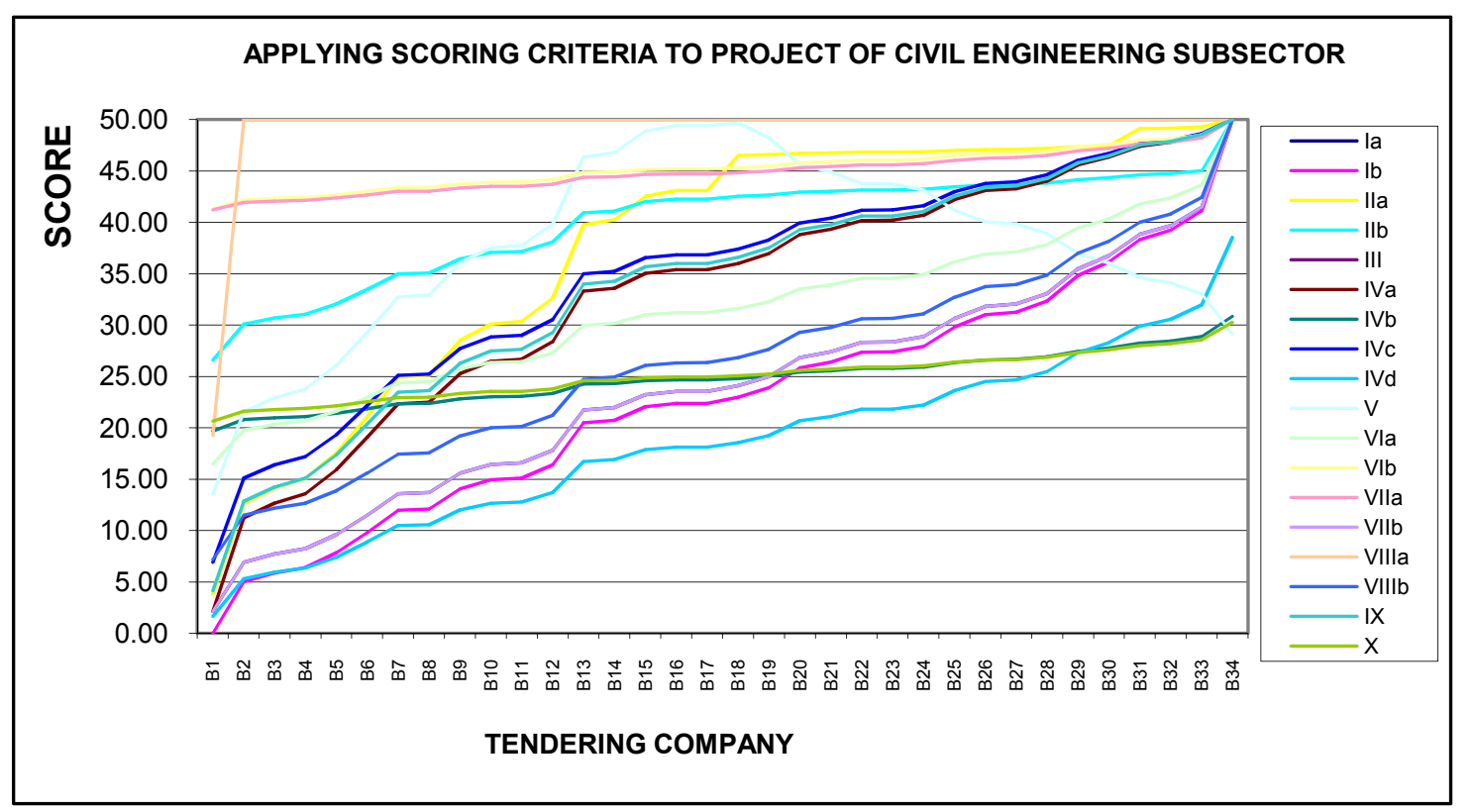

Figure 10. Applying Scoring Criteria to data from the economic results of the Project of Civil Engineering Subsector. 


\section{Conclusions}

The first point to be noted as a result of analysis of the scoring formulas behind economic criteria is the amount and disparity of the formulas. This means that the government must regulate common rules or formulae for all procedures, or at least establish some guidelines depending on the type of work, the number of bidders or the amount of money involved.

The next issue would be to eliminate the use of formulae that give the highest score to companies whose bid is nearest to the average of all bids submitted (group V). This is because it undermines the concept of the optimum bid and because it determines policy directives. Other scoring formulae which need to be reformed or even eliminate dare included in group VIII. As the score awarded is based on a drop of the tender price, limiting the maximum score to a certain percentage will there by allowing the government to fix the price at the amount necessary to carry out the work avoiding any highest drop compensation in scoring. Therefore, the importance of price in the award allocation process disappears.

Choosing the optimal formula of all options studied is a complex issue and could interfere with the contracting authorities' free reign which has been granted by the regulations. However, if guidelines we established, they should relate to the most suitable of criteria. The main objective would be to achieve proportionality between offers (or drops) and the scores received. It seems clear that the lowest bid should get the highest score and that guaranteed minimum score should exist. This would allow for the Scoring Gradient to start at zero points (if that score is awarded to the highest bid) or from the difference between the drop and the tender price up to the highest score of the economic criteria.

The slope of the score curve is what the contracting authorities should carefully define in order to find formulae with moderate or strong scoring gradients across various stages or phases, thereby giving more weight to economic criteria in the award allocation process as set out in the various administrative clauses. When selecting these moderate or strong scoring gradients, another possibility is to stagger them across various phases, with higher slopes in the initial stages to achieve minimum bids every time, and then scoring groups with less intense gradients which would also result in awarding bolder tenderers with higher scores.

\section{References}

[1] Rothkopf, M.H. "A model of rational competitive bidding". Management Science. 15 (7) , p. 362-373 , 1969. DOI: 10.1287/mnsc. 15.7.362.

[2] Näykki, P. “On optimal bidding strategies". Management Science. 23 (2) , p. 687-705, 1976. DOI: 10.1287/mnsc.23.2.198.
[3] Naoum, S.G. "Critical analysis of time and cost of management and traditional contracts". Journal of Construction Engineering and Management. 120 (4), p. 687-705, 1994. DOI: 10.1061/(ASCE)0733-9364(1994)120:4(687).

[4] Rothkopf, M.H. and Harstad, R.M. "Modeling competitive bidding: a critical essay". Management Science. 40(3), p. 364-384, 1994. DOI: $10.1287 / \mathrm{mnsc} .40 .3 .364$.

[5] Jennings, E. and Holt, G.D. "Prequalification and multi-criteria selection - a measure of contractor's opinion". Construction Management and Economics. 16(6), p.651-660, 1998. DOI: 10.1080/014461998371944.

[6] Kumaraswamy, M.M. and Walker, D.H.T. "Multiple performance criteria for evaluating construction contractors". Procurement Systems - A guide to Best Practice in Construction, London: E \& F N Spon, 1999, p 228-251.

[7] Wong, C.H., Holt, G.D. and Harris, P. "Multi-criteria selection o lowest price? Investigation of UK construction clients' tender evaluation preferences". Engineering, Construction and Architectural Management. 8(4), p.257-271, 2001. DOI: 10.1108/eb021187.

[8] Shen, L.Y., Li, Q.M., Drew, D. and Shen, Q.P. "Awarding construction contracts on multicriteria basis in China". Journal of Construction Engineering and Management. 130 (3), p.204-209, 2004. DOI: 10.1061/(ASCE)0733-9364(2004) 130:3 (385).

[9] Waara F. and Bröchner J. "Price and Nonprice Criteria for Contractor Selection". Journal of Construction Engineering and Management. 132(8), p. 797-804, 2006. DOI: 10.1061/(ASCE)0733-9364(2006)132:8(797).

[10] Lam, K.C., Ng, S.T., Tiesong, H., Skitmore, M., and Cheung, S.O. "Decision support system for contractor pre-qualification-artificial neural network model" Engineering Construction and Architectural Management. 7 (3), p. 251-266, 2000. DOI: 10.1108/eb021150.

[11] Bendaña, R., Del Caño, A. and De la Cruz, P. "Contractor selection: fuzzy control approach". Canadian Journal of Civil Engineering, 35 (5), p. 473-486, 2008. DOI: $10.1139 / 107-127$.

[12] Nieto-Morote, A. and Ruz-Vila, F. "A fuzzy multi-criteria decision-making model for construction contractor prequalification". Automation in Construction. 25, p. 8-19, 2012. DOI: 10.1016/j.autcon.2012.04.004.

[13] Pastor-Ferrando, J.P., Aragonés-Beltrán, P., Hospitaler-Pérez, A. and García-Melón, M. "An ANP and AHP based approach for weighting criteria in public works bidding". Journal of the Operational Research Society. 61, p. 905-916, 2010. DOI: 10.1057/jors.2010.13.

[14] Tone, K. "A slacks-based measure of super-efficency in data envelopment analysis". European Journal of Operational Research. 143 (1), p. 32-41, 2002. DOI: $10.1016 / \mathrm{S} 0377-2217(01) 00324-1$.

[15] Falagario, M., Sciancalepore, F., Costantino, N. and Pietroforte, R. "Using a DEA-cross efficiency approach in public procurement tenders" European Journal of Operational Research. 218 (2), p. 523-530, 2012. DOI: 10.1016/j.ejor.2011.10.031. 
[16] Crowley, L.G. and Hancher, D.E. "Risk assessment of competitive procurement". Journal of Construction Engineering and Management. 121(2), p. 230-237, 1995. DOI: 10.1061/(ASCE)0733-9364(1995)121:2(230).

[17] Tan, Y.T., Shen, L.Y. and Khalid, A.G. "An examination of the factors affecting contractor's competition strategy: a Hong Kong study". International Journal of Project Organisation and Management. 1, p. 4-23, 2008. DOI: 10.1504/IJPOM.2008.020026.

[18] Oo, B., Drew, D.R. and Runeson, G. "Competitor analysis in construction bidding". Construction Management and Economics. 28(12), p. 1321-1329, 2010. DOI: 10.1080/ 01446193.2010.520721.

[19] Mohamed-Khaled, A., Khoury-Shafik, S. and Hafez-Sherif, M. "Contractor's decision for bid profit reduction within opportunistic bidding behaviour of claims recovery". International Journal of Project Management. 29, p. 93-107, 2011. DOI: 10.106/j.ijproman.2009.12.003.

[20] Ballesteros-Pérez, P., González-Cruz, M.C. and Pastor-Ferrando, J.P. "Analysis of construction projects by means of value curves". International Journal of Project Management. 28(7), p. 719-731, 2010. DOI: 10.1016/ j.ijproman.2009.11.003.

[21] Ballesteros-Pérez, P., González-Cruz, M.C., Pastor-Ferrando, J.P. and Fernández-Diego, M. "The iso-Score Curve Graph. A new tool for competitive bidding". Automation in Construction. Vol 22, p. 481-490, 2012. DOI: 10.1016/j.autcon.2011.11.007.

[22] European Union. Directiva 2004/18/CE del Parlamento Europeo y del Consejo, de 31 de Marzo de 2004, sobre coordinación de los procedimientos de adjudicación de los contratos públicos de obras, de suministro y de servicios.
Diario Oficial de la Unión Europea, 30 de Abril de 2004, L 134 p.114-240.

[23] Spain. Real Decreto Legislativo 3/2011, de 14 de Noviembre, por el que se aprueba el texto refundido de la Ley de Contratos del Sector Público. Boletín Oficial del Estado, 16 de Noviembre de 2011, núm. 276, p.117729-117914.

[24] De Hoyos-Maroto, B. "Criterios de selección y criterios de adjudicación en la contratación administrativa: problemas de delimitación”. Cuenta con el IGAE. 11, p.30-36, 2005.

[25] Fueyo-Bros, M. "Criterios objetivos de valoración versus objetivos de los criterios de adjudicación". El Consultor de los Ayuntamientos y de los Juzgados. 15-16, p. 2196-2280, 2010 .

[26] Watt, D.J., Kayis, B. and Willey, K. "The relative importance of tender evaluation and contractor selection criteria". International Journal of Project Management. 28(1), p. 51-60, 2010. DOI: 10.1016/j.ijproman.2009.04.003.

[27] ABSAC. Report 28/95, de 14 de Octubre de 1995. Interpretación y aplicación que debe darse a lo previsto en el artículo 87 de la Ley de Contratos de las Administraciones Públicas, referido a los criterios para la adjudicación del concurso.

[28] Ballesteros-Moffa L.A. "La selección del contratista en el Sector Público: Criterios reglados y discrecionales en la valoración de las ofertas". Revista de Administración Pública. 180 , p. 21-57, 2009.

[29] ABSAC. Report 27/98, de 11 de Noviembre de 1998. Ponderación del criterio del precio en concursos.

[30] European Comission. Report 23/12/1997 en relación al procedimiento de adjudicación de un contrato de consultoría y asistencia del Gobierno español.. 